\title{
Phenology, fruit production and seed dispersal of Astrocaryum jauari (Arecaceae) in Amazonian black water floodplains
}

\author{
Maria Teresa F. Piedade ${ }^{1}$, Pia Parolin ${ }^{2}$ \& Wolfgang J. Junk ${ }^{2}$ \\ INPA/Max Planck, C.P. 478, 69011 Manaus, Am, Brazil. \\ Max-Planck-Institute for Limnology, Tropical Ecology, P.O. Box 165, 24302 Plön, Germany; \\ pparolin@mpil-ploen.mpg.de
}

Received 28-VII-2004. Corrected 14-VII-2005. Accepted 09-VIII-2006.

\begin{abstract}
Astrocaryum jauari Mart. (Arecaceae) is one of the commonest palm species occurring in nutritionally poor Amazonian black water floodplains. It is an emergent or subcanopy tree that grows on river banks and islands, with a wide distribution along the entire flooding gradient, tolerating flood durations between 30 and 340 days. The species is important for fish nutrition in the floodplains, and is also used for hearts of palm. In the present study, the auto-ecology of A. jauari w,as analysed over a period of two years in the Anavilhanas Archipelago, Rio Negro, Brazil, with a focus on phenology, fruit production, and seed dispersal. Fruit fall is annual and synchronized with high water levels, with a production of 1.6 ton of fruit $\mathrm{ha}^{-1}$. The fruits are eaten by at least 16 species of fish which either gnaw the pulp, fragment the seed, or ingest the entire fruit, thus acting as dispersal agents. Besides ichthyocory, barochory (with subsequent vegetative propagation) is an important dispersal mode, enhancing the occurrence of large masses of individuals in the Anavilhanas islands and in the region of maximum palm heart extraction near Barcelos. Rev. Biol. Trop. 54 (4): 1171-1178. Epub 2006 Dec. 15.
\end{abstract}

Key words: Astrocaryum jauari, floodplains, Amazonia, Anavilhanas, Brazil, ichthyocory, barochory.

Floodplain forests of large rivers in the Amazon region are subjected to water level fluctuations of about $10 \mathrm{~m}$ every year, as the result of the sum of the precipitation in the catchment area (Goulding 1983). The regular annual occurrence of an aquatic and a terrestrial phase is of high ecological importance (Junk et al. 1989) and led to the evolution of a specific vegetation (Kubitzki 1989, Prance 1979) highly adapted to survive partially or totally submerged periods of up to 210 days, depending on the position of the individuals in the flooding gradient (Junk 1993).

According to the water properties of the related rivers and the flora, two major floodplain ecosystems can be distinguished, the nutritionally rich „várzea“ associated to white water rivers like the Amazon, and the nutritionally poor ,igapós“, associated to black water rivers like the Rio Negro (Sioli 1975,
Prance 1980). Owing to the high acidity, mineral content and low light penetration in the igapós, aquatic herbaceous vegetation (Junk and Piedade 1997) and phytoplancton production (Sioli 1976, Schmidt 1973) are very poor. Life in this ecosystem therefore strongly depends on the allochtone primary production of the riparian forests (Erwin and Adis 1982, Junk et al. 1989, Junk and Piedade 1997).

In flooded forests, several plants dispersed by animals developed hard pericarps to protect the seeds against the acids of their digestive apparatus (Cronquist 1974). In such environments, the sound of fruit falling into the water can attract dispersors like fish (Van der Pijl 1969), particularly if the fruits are heavy like those of palm trees. One of these, Astrocaryum jauari Mart. (Fig. 1A, B), which is frequent in the black water floodplains of the Rio Negro and its affluents, produces fruits which 

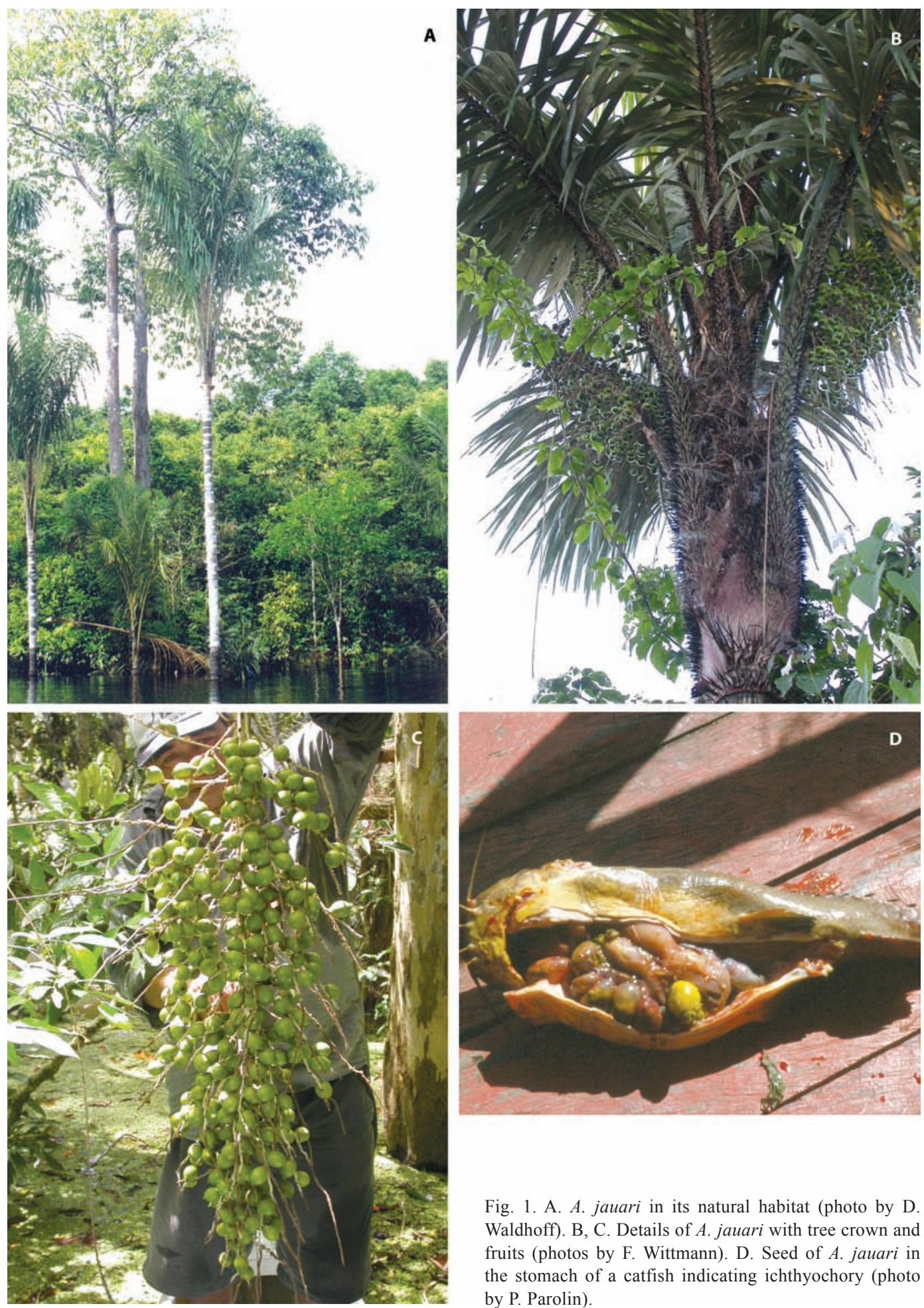

Fig. 1. A. A. jauari in its natural habitat (photo by D. Waldhoff). B, C. Details of A. jauari with tree crown and fruits (photos by F. Wittmann). D. Seed of A. jauari in the stomach of a catfish indicating ichthyochory (photo by P. Parolin). 
are consumed by fish (Fig. 1C; Gottsberger 1978, Goulding 1980, 1983). The commercially important Characidae family, and especially two of the most important fish in terms of local consumption and exportation, Colossoma bidens (pirapitinga) and Colossoma macropomum (tambaquí), feed on A. jauari and disperse its seeds (Goulding 1980). However, the fish may act also as predators, since they posses strong mandibles able to triturate the hard seeds.

Also the species' exploitation by man is considerable. The traditional use by indigenous people has been documented: A. jauari provides fiber, food, and shelter (Gragson 1992). In Puerto Ayacucho in the State of Amazonas, Venezuela, at least four indigenous groups (Piaroa, Curripaco, Guahibo and Baniva) from ten neighboring communities, include palm products in the economic support of their families (Narvaez and Stauffer 1999). Owing to the high quality and tenderness of the hearts of palm, this species was exploited for more than 20 years, supplying all hearts of palm commercialized in Central Amazonia between 1978 and 1998 (Piedade 1985, Piedade et al. 2003) before being replaced by Bactris gasipaes from plantations (Alírio Rocha, pers. comm. SHARP S/A).

Although the species is common and of high ecological importance, information about the vegetative and reproductive phenologies, and their timing with respect to the flood pulse, is completely missing. Dispersal mechanisms and their relationship with the local distribution and population structure as well as the contribution of fruits to the food chains are analyzed in the present study.

\section{MATERIALS AND METHODS}

Study sites: Data on phenology and on fruit production were collected in the
Anavilhanas Archipelago, Rio Negro, Central Amazon, at the Anavilhanas Ecological Floating Station (AEFE) of the Brazilian Institute of Environment (Instituto Brasileiro de Meio Ambiente - IBAMA), about $100 \mathrm{~km}$ from the city of Manaus (between $2^{\circ} 00^{\prime}$ and $3^{\circ} 02^{\prime} \mathrm{S}$ of latitude and $60^{\circ} 27^{\prime}$ to $61^{\circ} 07^{\prime} \mathrm{W}$ of longitude).

The main period of data collection was from August 1980 to November 1982. From this year to 1998 irregular field trips added occasional observations, and data about the commercial extraction of the palm tree were collected.

Climate: The climate is hot and humid with mean minimum temperatures above $18{ }^{\circ} \mathrm{C}$ (Ribeiro 1976). The most arid month (October) has a relative humidity above $60 \%$. Mean annual precipitation ranges between 1000 and $2500 \mathrm{~mm}$ (Fig. 2; Irmler 1975). Annual river level fluctuations in the Anavilhanas Archipelago show a similar pattern and amplitudes like those measured at the harbour in Manaus, with an annual mean amplitude of 10 m (Fig. 2; Schmidt 1973).

Vegetation: In the study sites, the vegetation forms three strata and has low plant densities. The taller trees reach 15 to $20 \mathrm{~m}$ height, with some emergent individuals about $25 \mathrm{~m}$ high (Piedade 1985). During high water levels, the vegetation is partially or totally inundated.

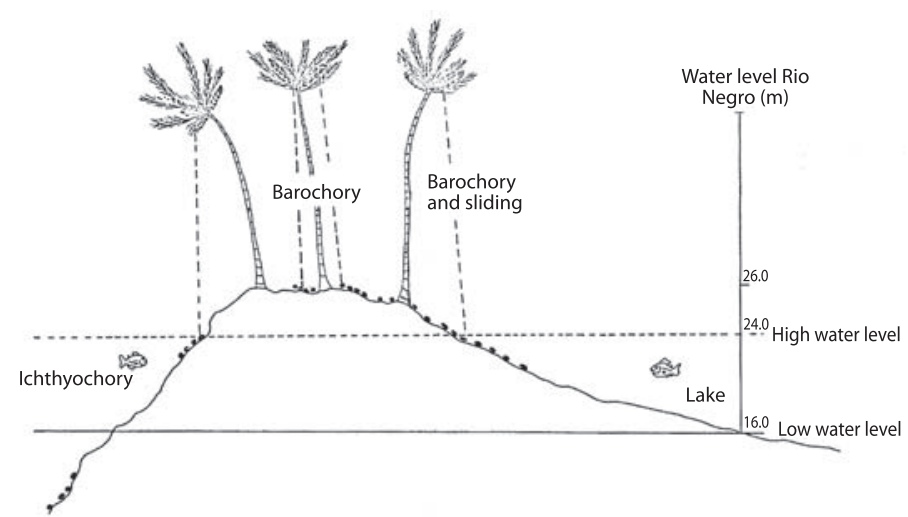

Fig. 2. Reproductive phenology of $A$. jauari in the study site near the Anavilhanas Ecological Floating Station (AEFE) in the Anavilhanas Archipelago, Rio Negro, Central Amazonia, with river level and precipitation. Young fruits are defined as green, less than $3 \mathrm{~cm}$ wide; mature fruits as yellowish. 
Medium height of mature $A$. jauari is $20 \mathrm{~m}$, with dense tree crowns, which have 6 to 14 leaves (Boer 1965), each one with a mean length of $3 \mathrm{~m}$. A. jauari may occur isolated but more frequently the species forms huge stands along the margins of rivers or lakes (Corrêa 1969, Goulding 1980). The species may form clones with 4 to 6 individuals differing in size but belonging to a single rhizome (Boer 1965).

Phenology and fruit production: Nine healthy, adult individuals of $A$. jauari were marked and the phenological status was recorded once a month. Presence or absence of flowers, young and mature fruits were recorded as well as fruit maturation time. In the period of fruit maturation, phenology was recorded at weekly intervals. Ten fruit bunches were collected from different individual trees, to ascertain total number of produced fruits and fruit weight and size. Twenty fruits per bunch were weighed. Additionally, 250 seeds were collected from different bunches for chemical analyses which were performed in the INPA, Manaus. Water content (in percent, after oven drying at $80{ }^{\circ} \mathrm{C}$ to constant weight), and the contents of protein, fat, ash, carbohydrates, calories and vitamin A were measured.

Dispersal: Dispersal syndromes were observed on the marked trees. To estimate predation, fruits were monitored for ten weeks as follows: 1000 fruits were collected from the bunches (pre-dispersal predation), and 3000 fruits were collected from the soil (post-dispersal predation). In order to establish the efficiency of water as a dispersal agent, 1000 seeds were collected floating at the water surface and opened to analyse the embrional integrity. Systematical analyses of fish stomach content were performed at the Ecological Station. To this information were added bibliographical data and interviews with local people.

Exploitation: Data on palm extractivism until 1998 were gained from the technicians of the Fábrica de Palmito Jauari, SHARP do Brasil S.A., Manaus/AM.

\section{RESULTS}

Phenology and fruit production: The production of flowers and fruits of $A$. jauari occurs once every year. The great majority of the adult palms starts the production of flowers when the water of the rivers are sinking and precipitation is not very intense yet, especially in August and September (Fig. 2). The flowering period is short and is soon substituted by the presence of small fruits which develop slowly. The fruits are mature when the river levels rise again, after about nine months, with abscission occurring mainly at high water levels in the months May to July (Fig. 2). No pre-dispersal predation was detected.

Every individual of $A$. jauari produces four fruit bunchs every year, which are $90 \mathrm{~cm}$ long on average and have a mean fruit number of 106, with a mean weight per fruit of $17 \mathrm{~g}$ (Table 1).

The chemical analyses of fruits of $A$. jauari (Table 2) show that the pulp and the seed consist mainly of water and carbohydrates, with a high percentage of fat $(14.7 \%)$ in the seed.

Dispersal: Since mean fruit weight is high (Table 1), and morphological features enhancing flotation are completely lacking, the fruits sink to the bottom when they fall into water. If fruits were found floating, then the seeds were not viable and all deteriorated. As a consequence of topographical conditions, after abscission the fruits may fall and be accumulated close to the mother plant (barochoric dispersal, Fig. 3). Under such conditions, some of the seeds may be predated by small coleoptera. They may also roll away from the mother plant, in many cases aided by the action of water. The fruits found in these conditions are less in number, and are located in isolated points on the islands. Ichthyochoric dispersal plays a major role: a total of 16 fish species feed on the fruits of $A$. jauari (Table 3 ). These belong to five families, mainly to the Characidae. Ten of the 16 species were categorized as possible dispersers, although three (C. macropomum, C. bidens and Prachtocephalus hemiliop- 
TABLE 1

Bunch size, total number of fruits, mean fruit fresh weight and fruit size

$\begin{array}{cccccc}\begin{array}{c}\mathrm{N}^{\circ} \text { of } \\ \text { bunch }\end{array} & \text { Bunch size }(\mathrm{m}) & \begin{array}{c}\text { Total number of } \\ \text { fruits }\end{array} & \begin{array}{c}\text { Mean fresh weight } \\ \text { per fruit }(\mathrm{g})\end{array} & \begin{array}{c}\text { Mean fruit } \\ \text { length }(\mathrm{cm})\end{array} & \text { Mean fruit width (cm) } \\ 1 & 1.07 & 218.00 & 14.98 \pm 2.1 & 3.49 \pm 0.5 & 2.71 \pm 0.2 \\ 2 & 0.99 & 73.00 & 17.38 \pm 4.9 & 3.59 \pm 0.6 & 2.85 \pm 0.3 \\ 3 & 0.68 & 68.00 & 22.23 \pm 5.5 & 4.21 \pm 0.8 & 3.05 \pm 0.2 \\ 4 & 0.85 & 146.00 & 14.80 \pm 2.6 & 3.78 \pm 0.5 & 2.68 \pm 0.2 \\ 5 & 0.96 & 114.00 & 15.88 \pm 3.1 & 3.86 \pm 0.3 & 2.74 \pm 0.3 \\ 6 & 1.00 & 79.00 & 26.80 \pm 6.2 & 4.45 \pm 1.0 & 3.24 \pm 0.4 \\ 7 & 0.88 & 152.00 & 11.50 \pm 2.9 & 3.51 \pm 0.6 & 2.43 \pm 0.4 \\ 8 & 0.87 & 148.00 & 10.53 \pm 4.2 & 3.27 \pm 0.3 & 2.28 \pm 0.3 \\ 9 & 0.85 & 29.00 & 19.01 \pm 5.1 & 3.80 \pm 0.8 & 2.94 \pm 0.2 \\ 10 & 0.93 & 29.00 & 17.53 \pm 2.6 & 3.80 \pm 0.6 & 2.89 \pm 0.3\end{array}$

TABLE 2

Chemical analysis of fruits of $\mathrm{A}$. jauari

\begin{tabular}{cccccccc}
\multicolumn{1}{r}{ Fruit part } & $\begin{array}{c}\text { Water } \\
\text { content (\%) }\end{array}$ & Proteins (\%) & Fat $(\%)$ & Ash (\%) & $\begin{array}{c}\text { Carbohydrates } \\
(\%)\end{array}$ & $\begin{array}{c}\text { Calories } \\
(\text { Kcal) }\end{array}$ & $\begin{array}{r}\text { Vitamin A } \\
(\text { U.I/100g) }\end{array}$ \\
Pulp (with peel) & 60.0 & 3.2 & 3.2 & 2.2 & 31.4 & 167.2 & 8500 \\
Seed & 42.4 & 3.2 & 14.7 & 0.8 & 61.1 & 389.5 & not det.
\end{tabular}

Results in g/100g of fresh weight. Analyses by Nutritional Department of INPA / Manaus, Brazil.

terus) may also act as predators since they do not only swallow the whole fruits, but sometimes chew and destroy them with their strong mandibles and teeth (Goulding 1980).
This could not be measured and quantified in the present study. In the whole study period, we did not observe any indications of other vertebrates feeding on fruits of $A$. jauari.

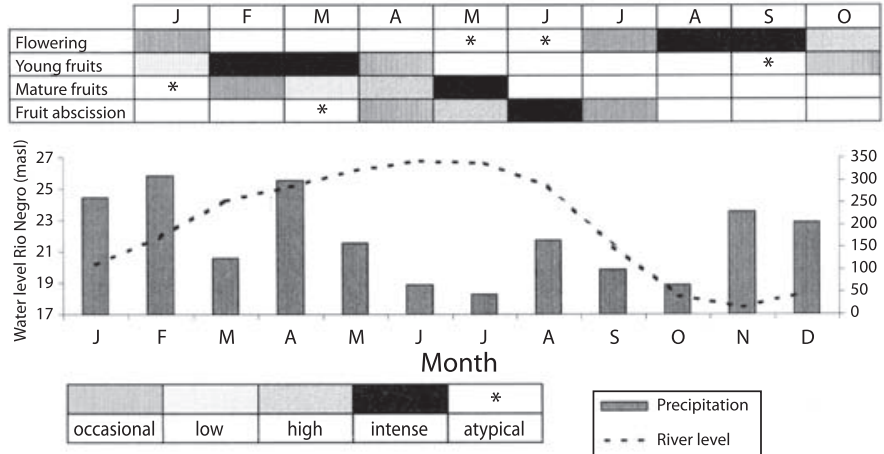

Fig. 3. Dispersal mechanisms of A. jauari. Schematic presentation with high and low water levels in a year of short flood duration.
Exploitation: Regarding the economic exploitation of $A$. jauari, the information provided by the Fábrica de Palmito Jauari-SHARP do Brasil S.A. indicate that in the region of the Municipality of Barcelos where the extractivism occurs, the density of the palms varies widely between river islands, from 250 to 2000 individuals/ha. One single worker can fell and pre-clean up to 90 palm trees 
TABLE 3

Fishes feeding on A. jauari fruits in Amazonian black water floodplains of the Anavilhanas Archipelago

\begin{tabular}{|c|c|c|c|c|c|}
\hline \multirow[t]{2}{*}{ Fish species } & \multirow[t]{2}{*}{ Common name } & \multirow[t]{2}{*}{ Family } & \multicolumn{3}{|c|}{ Exploitation of $A$. jauari } \\
\hline & & & swallow & break & nag \\
\hline Colossoma macropoтит & Tambaqui & Characidae & $\mathrm{xx}$ & $\mathrm{xxx}$ & \\
\hline Colossoma bidens & Pirapitinga & Characidae & $\mathrm{xx}$ & $\mathrm{xxx}$ & \\
\hline Brycon sp. & Jatuarana & Characidae & $\mathrm{x}$ & & $\mathrm{x}$ \\
\hline Brycon cf. melanopterus & Matrinchão & Characidae & $\mathrm{xx}$ & & $\mathrm{x}$ \\
\hline Myleus spp. / Metynnis spp. & Pacú & Characidae & & & $\mathrm{xx}$ \\
\hline Serrasalmus spp. & Piranha & Characidae & & & $\mathrm{x}$ \\
\hline Leporinus spp. & Aracú & Anostomidae & & & $\mathrm{x}$ \\
\hline Phractocephalus hemiliopterus & Pirarara & Pimelodidae & $\mathrm{xx}$ & $\mathrm{x}$ & \\
\hline Paulicea lutkeni & Pacamú (Jaú) & Pimelodidae & $\mathrm{xx}$ & & $\mathrm{x}$ \\
\hline Rhamdia schomburgkii & Jandiá & Pimelodidae & $\mathrm{x}$ & & \\
\hline Lithodoras dorsalis & Bacú-pedra & Doradidae & $\mathrm{x}$ & & $\mathrm{x}$ \\
\hline Megalodoras irwini & Rebeca & Doradidae & $\mathrm{xx}$ & & \\
\hline Oxydoras niger & Cuiu-cuiu & Doradidae & $\mathrm{x}$ & & \\
\hline Semaprochilodus spp. & Jaraqui & Prochilodontidae & & & $\mathrm{x}$ \\
\hline
\end{tabular}

At high water (May to July) (data from Goulding 1980, 1983 from stomach content fish analyses performed at the Anavilhanas Ecological Station, from interviews with local people, and from G. Borges and M.C.L.B. Ribeiro, pers. comm.). xxx high, xx mean, $x$ low frequency.

in the high water season in the months of May to June and about 25 in the low-water season (December, January). Calculating a number of ten workers in the area of Barcelos, 250 to 900 palms are exploited every day, corresponding to $0.5-1$ ha. From one palm $0.5-1$ bin of hearts of palm may be obtained. From October 1998 on, due to difficulties in keeping up a constant production, hearts of palm production of the SHARP S.A. was completely substituted by the palm B. gasipaes H.B.K (pupunha) which were planted on a 45 ha area with a total of 225000 palm trees.

\section{DISCUSSION}

The distribution of $A$. jauari was quite variable among different islands, occurring on sites flooded for 270 to 340 days per year on one island, while on an adjacent island they dominated in areas flooded for 30 to 200 days per year. This high amplitude of distribution was already pointed out by Huber (1906) for populations of $A$. jauari along the Rio Purus. It is possible because the palm is well-adapted anatomically and physiologically to hypoxic conditions (Schlüter et al. 1993). Annual inundation for as long as 300 days, at water temperatures of $28{ }^{\circ} \mathrm{C}$, produce neither leaf loss nor rotting of the roots. Well-developed aerenchyma permits gas transport from the branches to the roots. At a depth of $1.2 \mathrm{~m}$ beneath black waters, the leaves in the crowns of the plants show little decrease in the amount of chlorophyll.

Phenological patterns between sites are quite similar. A. jauari synchronizes its flowering with the period in which precipitation is less intense. With the onset of high precipitations, the fruits are growing already -a process which may last nine months- and at highest 
water levels the abscission of mature fruits is at its maximum. Perhaps this long period of maturation is necessary to reach the high energetic and vitaminic level of the fruits (Table 2), since the soils of the black water floodplains are extremely poor in nutrients (Sioli 1976). The long maturation phase is also necessary for the synchronization of fruit production with high water levels and the related seed dispersal by fish. The high nutritional value of the fruits (Table 2) may be related to the ichthyochoric dispersal syndrome. The especially high content of vitamin A may be advantageous for fish to put up stock reserves in the form of fat which are needed for gonads development in the low water period when food resources are scarce. Goulding (1980) found 52 entire fruits of $A$. jauari in only one individual of C. macropomum, and in one individual of $C$. bidens he found $1 \mathrm{~kg}$ of $A$. jauari fruits. The noise of fruits falling into the water attracts fish and thus contribuites to the success of the propagation mechanism.

All floating fruits were no longer viable, indicating that hydrochory does not play a role in A. jauari. Although Corner (1966) emphasizes that in the genus Astrocaryum dispersal by flotation is frequent and apparent, in the case of $A$. jauari the heavy fruits may eventually be transported submerged by currents, but definitely not by flotation.

The observed local increases of population density probably result from barochory, and from vegetative propagation which enhances the occurrence of large masses of individuals in the Anavilhanas islands, and of even higher densities in the region of maximum extractivism, near Barcelos.

Hydrochory is probably of neglectable importance, and ichthyochory is responsible for long distance dispersal helping to colonize new habitats. Van der Pijl (1969) states that ichthyochory is a primitive dispersal mechanism which in floodplains of Amazonia and Borneo has been maintained in ancient plant groups. These primitive mechanisms of dispersal usually imply a huge production and loss of fruits, since these mechanisms are highly hazardous in terms of the possibility of finding an appropriate place for germination, and they allow several opportunists to exploit the resource (Janzen 1970 1971, Fleming and Heithaus 1981).

Finally both, the intensive extraction of the palm, and the pressure over the populations of the most probable fish acting as dispersors may lead to the impoverishment of food chains in black water Amazonian floodplains, and to the decline of densities of A. jauari and some of the economically important fish species.

\section{RESUMEN}

Astrocaryum jauari Mart. (Arecaceae) es una de las especies más comunes de palma en las llanuras de inundación por las llamadas "aguas negras", aguas ricas en taninos que tienen pocos nutrientes para la fauna. Habita el subdosel que se desarrolla en riberas e islas, con una distribución amplia en toda la gradiente de inundación (resiste entre 30 y 340 días bajo el agua). La especie es importante para la nutrición de los peces y en la producción de palmito. La autoecología de $A$. jauari fue analizada por dos años en el Archipiélago Anavilhanas, río Negro, Brazil, con énfasis en fenología, producción de frutas, y dispersores de semillas. La caída de los frutos es anual y sincronizada con el aumento de los niveles de agua, con una producción de 1.6 ton de fruta $\mathrm{ha}^{-1}$. Las frutas son comidas por al menos de 16 especies de peces que roen la pulpa o fragmentos de semilla, o ingieren la fruta entera y actúan como agentes dispersores. Además de la ictiocoria, la barocoria y la subsecuente progragación asexual son básicos para la alta densidad de la especie.

Palabras clave: Astrocaryum jauari, llanura de inundación, Amazonía, Anavilhanas, Brasil, ictiocoria, barocoria.

\section{REFERENCES}

Boer, J.E.W. 1965. Palmae 5, p. 125-141. In J. Lanjouw (ed.). Flora of Suriname. E.J. Brill, Leiden, Holland.

Corner, E.J.H. 1966. The natural history of palms. Weidenfeld and Nicholson, London, England. 393 p.

Corrêa, M.P. 1969. Dicionário de plantas úteis do Brasil. IBDF, Rio de Janeiro, Brasil. 765 p.

Cronquist, A. 1974. The evolution and classification of flowering plants. Houghton Mifflin, Boston, Massachussetts, USA. 396 p. 
Erwin, T. \& J. Adis. 1982. Amazonian inundation forests: their role as short-term refuges and generators of species richness and taxon pulses, p. 358-371. In G.T. Prance (ed.). Biological diversification in the tropics. Columbia, New York, USA.

Fleming, T.H. \& E.R. Heithaus. 1981. Frugivorous bats, seed shadows and the structure of tropical forests. Biotropica 13: 45-53.

Gottsberger, G. 1978. Seed dispersal by fish in the inundated regions of Humaitá, Amazonia. Biotropica 10: 170-183.

Goulding, M. 1980. Interactions of fish with fruits and seeds, p. 217-232. In M. Goulding (ed.). The fishes and the forest. Explorations in Amazonian natural history. California, California, USA.

Goulding, M. 1983. The role of fishes in seed dispersal and plant distribution in Amazonian floodplain ecosystems. Sonderbd. Naturwiss.Hamburg, Germany 7: $271-283$

Gragson, T.L. 1992. The use of palms by the Pume Indians of southwestern Venezuela. Principes 36: 133-142.

Huber, J. 1906. La végétation de la vallée du rio Purus (Amazone). Bull. Herb. Boissier 4: 249-276.

Irmler, U. 1975. Ecological studies of the aquatic soil invertebrates in three inundation forests of Central Amazonia. Amazoniana 3: 337-409.

Janzen, D.H. 1970. Herbivores and the number of tree species in tropical forests. Am. Nat. 104: 501-528.

Janzen, D.H. 1971. Seed predation by animals. Ann. Rev. Ecol. Syst. 2: 465-492.

Junk, W.J., P.B. Bayley \& R.E. Sparks 1989. The flood pulse concept in river-floodplain systems. Can. Publ. Fish. Aquat. Sci. 106: 110-127.

Junk, W.J. \& M.T.F. Piedade 1997. Plant life in the floodplain with special reference to herbaceous plants, p. 147-186. In W.J. Junk (ed.). The Central Amazonian Floodplain: Ecology of a Pulsing System. Ecological Studies, Vol. 126. Springer, Berlin, Germany.

Junk, W.J. 1993. Wetlands of tropical South America, p. 679-739. In D.F. Whigham, D. Dykyjová \& S. Hejný (eds.). Wetlands of the World I. Kluwer Academic, Holland.

Kubitzki, K. 1989. The ecogeographical differentiation of Amazonian inundation forests. Plant Syst. Evol. 162: 285-304.

Narvaez, A. \& F. Stauffer. 1999. Products derived from palms at the Puerto Ayacucho markets in Amazonas State, Venezuela. Palms 43: 122-129.

Piedade, M.T.F. 1985. Ecologia e biologia reprodutiva de Astrocaryum jauari Mart. (Palmae) como exemplo de populaçao adaptada as áreas inundáveis do rio Negro. Master Thesis, INPA Manaus, Brasil. 184 p.

Piedade, M.T.F., P. Parolin \& W.J. Junk. 2003. Estratégias de dispersão, produção de frutos e extrativismo da palmeira Astrocaryum jauari Mart. nos igapós do Rio Negro: implicações para a ictiofauna. Ecol Appl 2: 31-40.

Prance, G.T. 1979. Notes on the vegetation of Amazonia. III. Terminology of Amazonian forest types subjected to inundation. Brittonia 31: 26-38.

Prance, G.T. 1980. A terminologia dos tipos de florestas amazonicas sujeitas a inundação. Acta Amazonica 10: 495-504.

Ribeiro, M.N.G. 1976. Aspectos climatológicos de Manaus. Acta Amazonica 6: 229-233.

Schlüter, U.B., B. Furch \& C.A. Joly. 1993. Physiological and anatomical adaptations by young Astrocaryum jauari Mart. (Arecaceae) in periodically inundated biotopes of Central Amazonia. Biotropica 25: 384-396.

Schmidt, G.W. 1973. Primary production of phytoplankton in the three types of Amazonian waters. Amazoniana 4: $135-203$.

Sioli, H. 1975. Tropical river: The Amazon, p. 461-488 In B.A. Whitton (ed.). River Ecology. California, California, USA.

Sioli, H. 1976. A limnologia na regiao amazônica brasileira. Anais do Encontro Nacional sobre Limnologia, Piscicultura e Pesca Continental. Belo Horizonte, Brazil. p. 153-169.

Van der Pijl, L. 1969. Principles of dispersal in higher plants. Springer, Berlin, Germany. 153 p. 